\title{
Red snapper fish intake improves thyroid gland activity in the hypothyroidism rat
}

\author{
*Herawati, E., Titisari, R.S., Husna, S.A.N., Astirin, O.P., Widiyani, T. and Listyawati, S. \\ Department of Biology, Faculty of Mathematics and Natural Sciences, Universitas Sebelas Maret. Jl. Ir. \\ Sutami No.36, Kentingan, Surakarta, Central Java 57126, Indonesia
}

\begin{abstract}
Article history:
Received: 7 December 2020

Received in revised form: 18

March 2021

Accepted: 7 June 2021

Available Online: 20 June

2021
\end{abstract}

Keywords:

Red snapper fish,

Hypothyroidism,

Thyroid hormone,

FT4,

TSH

DOI:

https://doi.org/10.26656/fr.2017.5(S2).007

\begin{abstract}
Congenital hypothyroidism is inadequate production of thyroid hormone in infants from birth. Treatment of hypothyroidism often involves an iodine-rich diet since iodine is a vital precursor for thyroid hormone synthesis. Red snapper fish is a saltwater fish that contain a high amount of iodine and other beneficial macro/micronutrients, yet no report was found on the effect of this fish consumption on hypothyroidism. The objective of this study was to determine the effectiveness of red snapper (Lutjanus sp.) fish on thyroid gland activity, manifested by low FT4 level and high TSH level, two diagnostic indicators of hypothyroidism. This study used a post-test and controlled group design. Pregnant female rats were given propylthiouracil orally for four weeks to induce hypothyroidism in their offspring. All hypothyroid offspring were divided into five treatment groups, i.e., negative control, positive control (thyroxin therapy), red snapper enriched diet at $25 \%$ and $50 \%$ dosage, also a combination of levothyroxine and red snapper. The thyroid gland activity was detected by measuring blood serum FT4 and TSH and histological examination of the thyroid gland using HE staining. The level of FT4 and TSH in each treatment group were analyzed with the one-way ANOVA test. The results showed that the group that received a 50\% red snapper diet has a normal level of FT4 and TSH, whereas the FT4 level increased two-fold; the TSH level decreased significantly. The organization of the thyroid gland showed a remarkable change of the lumen diameter, indicating a higher amount of hormone production by the gland.
\end{abstract}

\section{Introduction}

The thyroid gland produces thyroid hormone, mainly triiodothyronine (T3) and thyroxine (T4). The thyroid hormone synthesis is affected by a feedback mechanism involving Thyroid Stimulating Hormone (TSH). Inadequate thyroid hormone production caused the human body unable to function normally, a condition called hypothyroidism. Individuals who have hypothyroidism have low FT4 and elevated TSH (Zimmerman et al., 2015). Therefore, blood TSH and FT4 level serve as diagnostic tool for hypothyroidism.

In fetus and infants, thyroid hormone deficiency (i.e., congenital hypothyroidism) can cause physical deformities, impaired neurological function, and cretinism. Cretinism is a severe thyroid hormone deficiency in the newborn, causing mental retardation, deaf, mute, and stunted growth (Rastogi and LaFranchi, 2010; Zimmerman et al., 2015). Globally, the prevalence of congenital hypothyroidism is 1:3000, and several countries showing a lower prevalence, e.g., 1:7000 in Japan, 1:3026 in Malaysia. In Indonesia, congenital hypothyroidism is still quite common. In 2000-2014, there were 85 newborns with congenital hypothyroidism detected from the total 213,669 birth, giving a ratio of 1:2513 (Mranani, 2014; Wassner and Brown, 2015). A higher congenital hypothyroidism prevalence ratio in Indonesia compared to the global ratio indicates an urgency to solve this problem.

Iodine is a crucial micronutrient needed to synthesize the thyroid hormone. Iodine deficiency causes low thyroid hormone production, which in turn causing several health problems. Groups prone to iodine deficiency are pregnant and breastfeeding women, also children. In pregnant women, the thyroid hormone helps the fetus develop. Deficiency of this hormone may increase the risk of metabolism and physiological activity problems, fetus growth and development, especially the nervous system and brain (Skeaff, 2011; Wassner, 2017). 
Most congenital hypothyroidism cases in Indonesia were due to the low iodine intake in pregnant women (Mranani, 2014). Therefore, consuming an iodine-rich diet is highly recommended during pregnancy (Alexander et al., 2017). Saltwater fish is one of the food sources containing a high amount of iodine. Low consumption of saltwater fish during pregnancy increased the risk of iodine deficiency by 3.44 times higher than a higher saltwater fish consumption (Alfitri et al., 2016). Indeed, several saltwater fishes from the Indonesian ocean, e.g., mackerel, large head hairtail, red snapper, jackfish, and ponyfish, have a high iodine content ranging between 91-118 $\mu \mathrm{g} / 100 \mathrm{~g}$ (Gunanti et al., 1999).

Patients with hypothyroidism need lifelong treatment that is effective and has minimal side effects. This research is intended to explore the benefits of saltwater fish consumption on alleviating hypothyroidism in human. Snapper fish, which is abundant, easy to access, and relatively cheap, contains iodine and other important nutrients making it a superior dietary alternative to improve hypothyroidism (Gunanti et al., 1999; Arai et al., 2015). However, the literature on the use of fish for hypothyroid therapy is still limited. Our recent study demonstrated that red snapper fish (Lutjanus sp.) contains a high amount of iodine $(93.8 \mu \mathrm{g} / 100 \mathrm{~g})$ and increased the number of pyramid cells in the rat (Rattus norvegicus) brain with hypothyroidism (Herawati et al., 2021). This study aimed to investigate the effect of red snapper-enriched diets on the FT4 and TSH hormones in rats with hypothyroidism. The results of this study could suggest a probable health solution with better overall effects so that the quality of life for people with hypothyroidism will improve.

\section{Materials and methods}

\subsection{Animal (rats) care}

The experiment using albino rat ( $R$. norvegicus) was performed by following guidelines and regulations of animal care facilities of Integrated Laboratory Units, Universitas Sebelas Maret (UNS), Indonesia. Ethical clearance with authorization number 477/UN27.06/ $\mathrm{KEPK} / \mathrm{EC} / 2019$ was provided by the Health Research Ethics Committee of the Faculty of Medicine, UNS. Rats used for the experiments were the wild-type SpragueDawley (SD) rats purchased from the Faculty of Pharmacy, Setia Budi University, Indonesia. There were eight rats (6 females and 2 males) provided with food and drink ad libitum and kept under controlled temperature, light, and humidity. The females mate with the males and the pups (i.e., infant rats) with a confirmed case of hypothyroidism were used for the experiments.
The method to induce hypothyroidism is described below.

\subsection{Inducing hypothyroidism in pregnant rats}

The pregnant rats were treated with a daily dose of $0.05 \%(\mathrm{w} / \mathrm{v})$ or Propylthiouracil (PTU) in their drinking water ad libitum for three weeks (week 3 pregnancy until day 21 lactation) (Donzelli et al., 2016, Bunker et al., 2017). To increase the solubility, PTU was dissolved in $100 \mathrm{ml}$ distilled water contained $25 \mathrm{ml}$ of $1 \%$ Carboxy Methyl Cellulose (CMC).

\subsection{Measurement of blood serum FT4 and TSH}

To confirm the pups' status of hypothyroidism, their blood serum FT4 and TSH were measured at the age of 4 weeks. The blood samples were collected using a capillary collector tube from the pups' orbital sinus. The blood samples were put on ice and allowed to clot, then centrifuged at $2000 \times g$ for 10 mins. Next, the measurement of FT4 and TSH level was done using the ELISA kit (CUSABIO, USA, Cat No. CSB-E05079r; CSB-E05115r, respectively) according to the manufacturer's instruction. The absorbance was measured on a microtiter plate reader (Bio-Rad). This part of the experiment was done at the Research and Development Center for Iodine Deficiency Disorders (Balai Penelitian dan Pengembangan Gangguan Akibat Kekurangan Yodium), Magelang, Indonesia. Data were analyzed using one-way ANOVA followed by Duncan's multiple range test. $p<0.05$ was considered significant.

\subsection{Treatment groups}

Pups (4 weeks old) confirmed with hypothyroidism were divided into five treatment groups containing three individuals each, i.e., (1) negative control, (2) positive control receiving levothyroxine (L-thyroxine), (3) 25\% red snapper dietary supplement, (4) 50\% red snapper dietary supplement, and (5) combination of thyroxine and $25 \%$ red snapper dietary supplement. Each treatment was given for four weeks.

\subsection{Diets and determination of iodine content}

This study used red snapper fishes (weighing 200 grams each) obtained from a local supermarket. To prepare the fish supplement, the fishes were cleaned, scaled, then steamed for 15 mins. The prepared fish mixed with basal diet broiler-2 (BR-2) at a ratio based on the treatment dose as described above. Rat group treated with red snapper enriched diet were fed twice a day with each serving constituted $10 \%$ of their body weight. Each rat was kept in an individual cage. The leftover food in each cage (if any) was weighed using a digital scale, including any food that had spilt onto the bottom of the 
cage. The recording of food intake was performed every $24 \mathrm{hrs}$. Determination of iodine concentrations was based on spectrophotometric measurements of the SandellKolhoff-reaction as described elsewhere (Keller, 1973).

\subsection{Oral administration of levothyroxine}

Levothyroxine sodium was prepared by dissolving it in aquadest until it reached a final concentration of 0.005 $\mu \mathrm{g} / \mathrm{g}$ and stored at $-20^{\circ} \mathrm{C}$. The solution was given by intragastric administration once per day to the positive control group.

\subsection{Histological analysis of thyroid gland}

All treated eight weeks old rats were euthanized using inhaled anaesthetics and the thyroid gland from each rat was extracted using a surgical instrument. The glands were preserved in $10 \%$ neutral buffered formalin for 2 days and embedded in paraffin. The preserved thyroid gland was sliced into sections of $5 \mu \mathrm{m}$, placed on glass slides, and counterstained with hematoxylin and eosin. The slides were examined, and images were taken using a digital microscope (Nikon ECLIPSE Ni-E) at $100 \times$ and $400 \times$ magnification. The diameter of a follicle's lumen was quantified based on the mean of two perpendicular lumens and the data were analyzed using the Chi-square test.

\section{Results and discussion}

The hypothyroid condition on rats used in this study was determined based on the decreased FT4 and increased TSH level compared to the normal condition (Soonawala et al., 2018). According to earlier studies, the normal thyroid hormone level of $R$. norvegicus was $28.4 \mathrm{pmol} / \mathrm{L}$ for FT4 (Zamoner et al., 2008) and 1.7 $\mathrm{mIU} / \mathrm{L}$ for TSH (Donzelli et al., 2016). This study showed that a month after PTU induction, all pups have a lower FT4 level $(<13.7 \mathrm{pmol} / \mathrm{L})$ compared with the normal condition and TSH level higher than normal (>1.7 mIU/L) (Figure 1). This result proved that PTU has effectively induced congenital hypothyroidism when given to pregnant rats as reported previously (Zamoner et al., 2008; Donzelli et al., 2016). The red snapperenriched diets were given to three groups of pups (4 weeks old) with confirmed congenital hypothyroidism during 4 weeks of treatments. After 4 weeks of treatments, these three rat groups showed significant changes in their level of FT4 and TSH towards the normal range compared to the negative control group (Figure $1 \mathrm{~A}-\mathrm{B}$ ).

The anatomical and histological observation of the rats' thyroid gland was consistent with their thyroid hormone level. Anatomically, the two lobes of the thyroid gland on the negative control group showed a
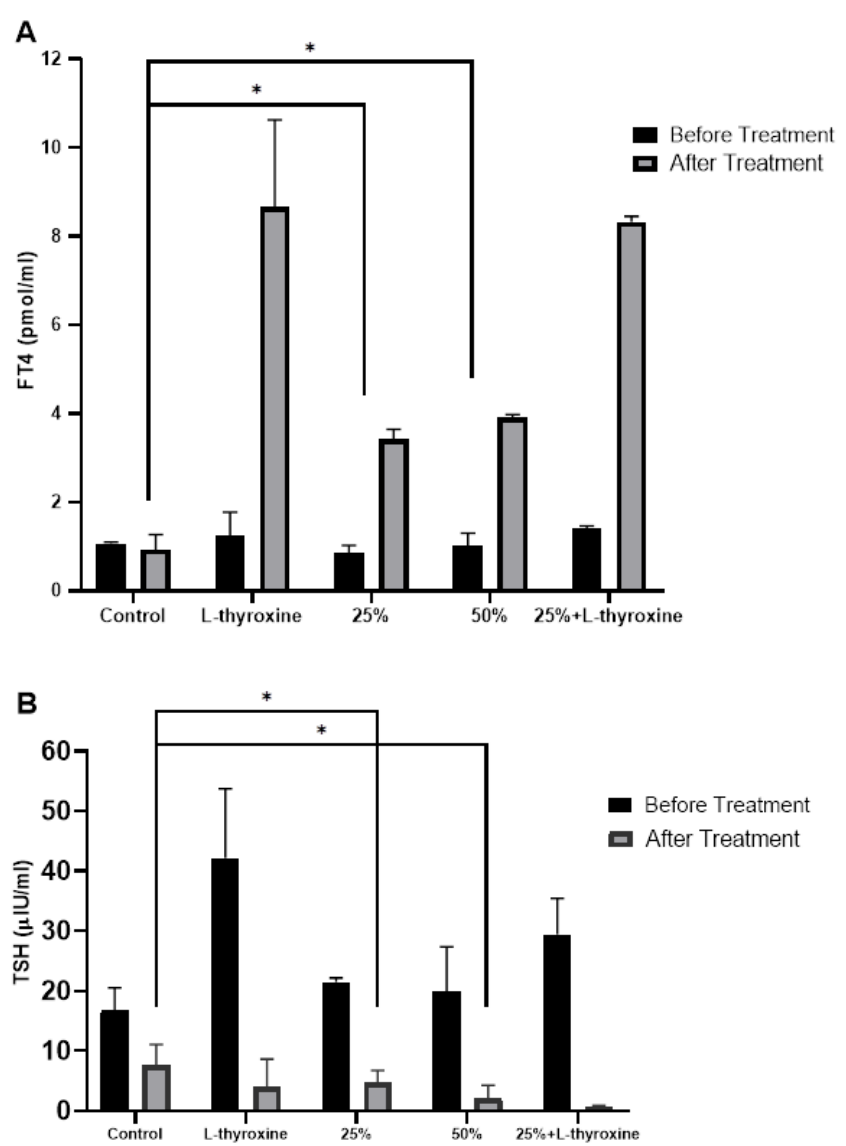

Figure 1 . The effect of red snapper dietary supplement on blood serum FT4 and TSH of rats with congenital hypothyroidism. (A) FT4 level before and after treatments (B) TSH level before and after treatments $(* \mathrm{p}<0.05)$.

bigger size compared to other groups of treatment (Figure 2). Based on the microscopical observation, the tissue structural organization of this group was also different compared with others, i.e., there were more follicles with smaller size and the shape of follicular cells were columnar. On the contrary, the thyroid gland on rats given red snapper-enriched diets consisted of a bigger size follicle filled with colloids, indicative of higher hormone production (Figure 3). The follicle is a structural and functional unit of the thyroid gland. Thyroid follicles act as storage compartments where the middle part contains colloid to store prohormone. In this study, the diameter of a follicle's lumen was quantified based on the mean of two perpendicular lumens (Figure 4). To simplify the data analysis, the diameter measurement results grouped into three diameter range

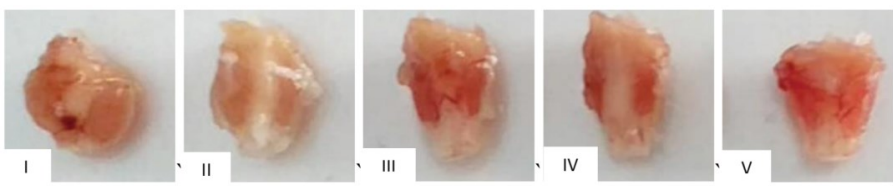

Figure 2. The thyroid gland lobes between different treatment groups of rats with congenital hypothyroidism. I: negative control, II: positive control with levothyroxine, III: $25 \%$ red snapper dietary supplement, IV: $50 \%$ red snapper dietary supplement, V: a combination of $25 \%$ red snapper dietary supplement and levothyroxine. 
groups, i.e., short $(0-33.3 \mu \mathrm{m})$, medium $(33.4-66.7$ $\mu \mathrm{m})$, and long $(66.8-100.0 \mu \mathrm{m})$ (Figure 5).



$25 \%$

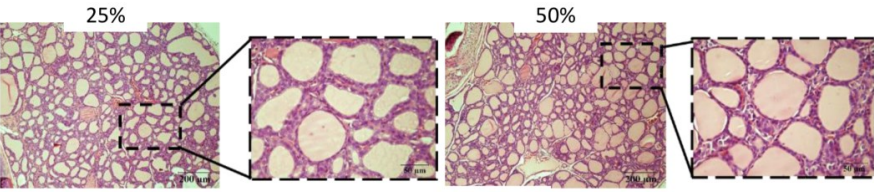

$25 \%+\mathrm{L}$-thvroxine



Figure 3. The histology of thyroid gland of congenital hypothyroid rats stained with hematoxylin and eosin (negative control, positive control with levothyroxine, $25 \%$ red snapper dietary supplement, $50 \%$ red snapper dietary supplement, a combination of $25 \%$ red snapper dietary supplement and levothyroxine).

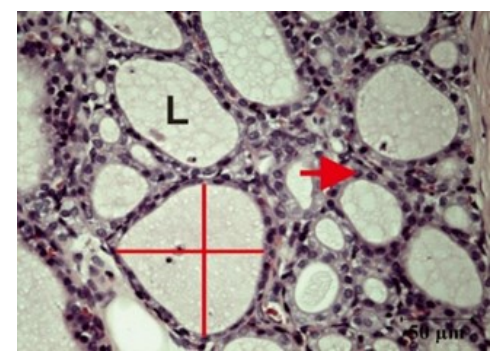

Figure 4. The lumen diameter of the thyroid gland's follicles



Figure 5. The diameter of the follicle thyroid lumen of congenital hypothyroid rats with different treatments (negative control, positive control with levothyroxine, 25\% red snapper dietary supplement, $50 \%$ red snapper dietary supplement, a combination of $25 \%$ red snapper dietary supplement and levothyroxine).

The follicle's lumen diameter of the rat group fed with a $25 \%$ red snapper enriched diet fell in the long $(10 \%)$, medium $(46 \%)$, and short (44\%) range. These diameter ranges were not significantly different when the dosage of red snapper supplement increased by $50 \%$. On the contrary, the negative control rats showed a significantly different result with a short $(85 \%)$ diameter range dominated the medium (15\%) (Figures 3 and 5). Further analysis with Chi-square showed a significant difference in the thyroid follicle's lumen diameter between groups of treatments. The longer diameter of colloid indicates a higher synthesis and secretion activity of the thyroid gland in rats treated with a red snapperenriched diet. The corrected FT4 and TSH level towards a normal condition after treated with a red snapper diet also signify this finding (Figure 1).

The variety of lumen size as shown in Figure 3 also indicates that a thyroid lobe can contain follicles with different activity levels. An irregular follicle size commonly found on six months old adult mice (Lee et al., 2016). Possibly, the changes observed in the thyroid glands' follicle suffering from a pathological condition (i.e., hypothyroidism) was due to external stimulation such as changes in TSH level and micronutrient supply provided by the red snapper supplement.

In normal physiological condition (euthyroid), thyroid hormone synthesis and secretion activity are under the normal range. The thyroid follicular cells surrounding the space filled with fluid (lumen) form a simple cuboidal epithelium (Figure 4, arrow) with medium size of lumen (Rajab et al., 2017; Khan and Farhana, 2019). The histological description of the thyroid gland in rats treated with a red snapper-enriched diet showed a similar physiological condition with the euthyroid mentioned (Figures 3 and 5). This result proves that red snapper contains a compound that initiates the synthesis and secretion activity of the thyroid gland. In hypothyroid condition, the stimulated follicular cells became highly active, columnar-shaped (hypertrophy), and experiencing hyperplasia (Figure 3) because TSH stimulates follicular cells to increase the thyroid hormone synthesis. TSH also stimulates the increase in thyroid hormone exocytosis rate, the coupling of thyroglobulin with iodine, and the breaking down of intracellular colloid. This overall process causes a drastic reduction in colloid's volume, which morphologically manifested by the thyroid gland enlargement (Figure 2) due to the continuous stimulation (Stelios et al., 2007 dan Zbucki et al., 2007).

The functional balance of the thyroid gland is strongly affected by the proper amount of iodine. Iodine is a trace element that cannot be synthesized by human bodies and can only be fulfilled by a proper dietary intake. Earlier epidemiological studies have reported a positive correlation between sufficient iodine intake and the low incidence of thyroid abnormalities (Ballester et al., 2010; Eastman and Zimmermann, 2018). The red snapper fish used in this study has a high iodine content (98.03 mg/100 g; Table 1) compared to other consumable saltwater fish captured in the Indonesian ocean (Gunanti et al., 1999). Snapper fish fillet also contains a high amount of tyrosine $(173 \%$ recommended 
daily intake per $600 \mathrm{~g}$ ), which is the thyroid hormone precursor (Citterio et al., 2019; Whitbread, 2020). Tyrosine is one of the amino acids which function as building blocks on the synthesis of thyroid hormone. Iodine will combine with tyrosine to form two types of thyroid hormone, i.e., T3 (triiodothyronine) and T4

Table 1. Iodine content on red snapper and BR-2

\begin{tabular}{cc}
\hline Ingredients & Iodine content $(\mu \mathrm{g} / 100 \mathrm{~g})$ \\
\hline Red snapper (steamed) & 98.03 \\
BR-2 & 45.16 \\
\hline
\end{tabular}

(thyroxine) in the thyroid gland.

The thyroid hormone is a vital regulator in cell proliferation and growth. Therefore, maintaining the thyroid hormone at the optimal level is crucially important to support normal growth and health. The clinical manifestation of a young hypothyroid patient is stunted growth (Zimmerman et al., 2015). In this study, the rats' growth was observed by measuring several parameters, i.e., weight, body length, and thorax circumference. The total daily meal intake recorded was the same since the rats always finished their daily meal, thus; the difference of growth in each group was not caused by different amount of food intake. The lowest growth curve was shown by the negative control group (Figure 6A-C). Stunted growth in hypothyroid rats showed that the thyroid hormone was crucially involved in the growth regulation during the fetal and postnatal periods through complex metabolism effects, stimulation of growth factor production, growth hormone (GH) secretion and action, and insulin-like growth factor (IGF1) (Mytilinaios et al., 2017; Teixeira et al., 2020). A higher growth parameter was shown in groups provided with red snapper diets (Figure 6A-C). The phenomena may be attributed to the normalization of the thyroid hormone level which promotes somatic growth. Nevertheless, the increase in weight gain on rats with red snapper-enriched diet groups might also cause by the nutritional value of red snapper feed. The rat's feed supplemented by $50 \%$ red snapper has a richer protein content (0.6-1.5\%) compared to the basal diet (BR-2) (Herawati et al., 2021). Our results showed that a red snapper-enriched diet at dosage $25 \%$ and $50 \%$ increase the thyroid hormone activity and support the growth of congenital hypothyroid rats.

\section{Conflict of interest}

The authors declare no conflict of interest.
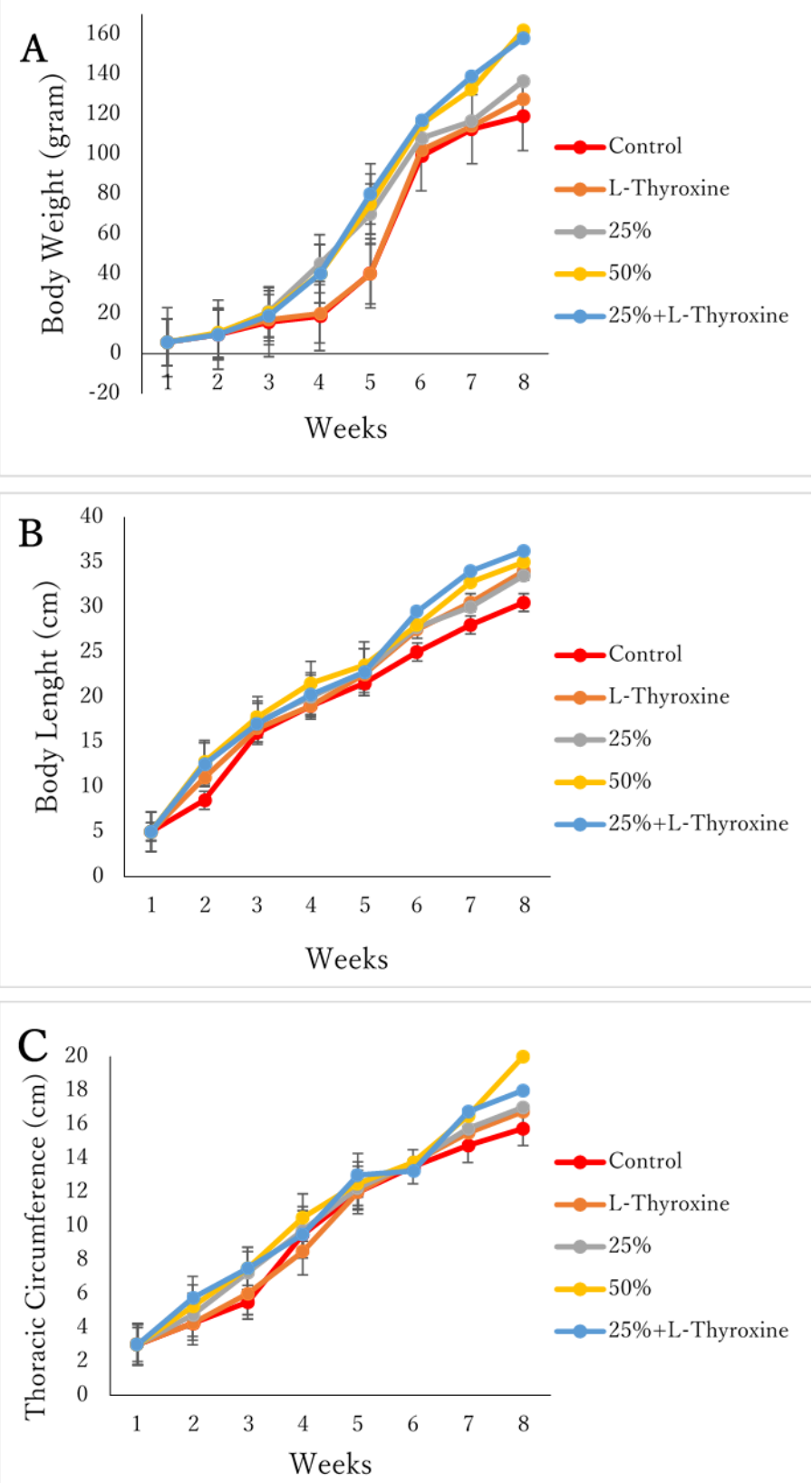

Figure 6. Several growth rate parameters of congenital hypothyroid rats with different treatments (A) weight gain, (B) body length, (C) thoracic circumference.

\section{Acknowledgments}

This work was funded by the PNBP Universitas Sebelas Maret research grant (No: 452/UN27.21/ $\mathrm{PN} / 2020)$.

\section{References}

Alfitri, A., Widodo, U. and Sudargo, T. (2016). Faktorfaktor pada kejadian GAKY ibu hamil di Tabunganen Barito Kuala, Kalimantan Selatan. Jurnal Gizi Dan Dietetik Indonesia, 1(1), 714. https://doi.org/10.21927/ijnd.2013.1(1).7-14. [In Bahasa Indonesia].

Alexander, E.K., Pearce, E.N., Brent, G.A., Brown, R.S., Chen, H., Dosiou, C., Grobman, W.A., Laurberg, P., Lazarus, J.H., Mandel, S.J., Peeters, R.P. and 
Sullivan, S. (2017). 2017 Guidelines of the American Thyroid Association for the diagnosis and management of thyroid disease during pregnancy and the postpartum. Thyroid, 27(3), 315-389. https:// doi.org/10.1089/thy.2016.0457

Arai, T., Amalina, R. and Bachok, Z. (2015). Variation in fatty acid composition of the bigeye snapper Lutjanus lutjanus collected in coral reef habitats of the Malaysian South China Sea. Journal of Biological Research-Thessaloniki, 22, 5. https:// doi.org/10.1186/s40709-015-0027-2

Ballester, L.V., Candil, S.D., Reymunde, T.I., Escofet, F.S., Henzi, F.T., Jaramillo, S.T., Alcazar, J., Tapias, M.J., Torres, Y. and Puig-Domingo, M. (2010). Assessment of dietary habits related to iodine intake and iodine concentration and thyroid disfunction in a non-preselected population in Spain (The Thyrobus Project). Endocrinology Nutrition, 57(9), 407-413. https://doi.org/10.1016/j.endonu.2010.04.012

Bunker, S.K., Dandapat, J., Chainy, G., Sahoo, S.K. and Nayak, P.K. (2017). Neonatal exposure to 6-n-propyl -thiouracil, an anti-thyroid drug, alters expression of hepatic DNA methyltransferases, methyl CpGbinding proteins, Gadd45a, p53 and PCNA in adult male rats. European Thyroid Journal, 6(6), 281-291. https://doi.org/10.1159/000479681

Citterio, C.E., Targovnik, H.M. and Arvan, P. (2019). The role of thyroglobulin in thyroid hormonogenesis. Nature Review Endocrinol, 15, 323 -338. https://doi.org/10.1038/s41574-019-0184-8

Donzelli, R., Colligian, D., Kusmic, C., Sabatini, M., Lorenzini, L., Accoroni, A., Nannipien, M., Saba, A., Lervasi, G. and Zucchi, R. (2016). Effect of hypotyroidism and hyperthyroidism on tissue thyroid hormone concentrations in rat. European Thyroid Journal, $\quad 5, \quad 27-34 . \quad \mathrm{https}: / /$ doi.org/10.1159/000443523

Eastman, C.J and Zimmermann, M.B. (2018). The iodine deficiency disorders. In Feingold, K.R. (Ed.) Endotext. Retrieved from NCBI website: https:// www.ncbi.nlm.nih.gov/books/NBK285556/

Gunanti, I. R., Suhardjo, S., Kusharto, C.M., Rimbawan, R. and Wijatmadi, B. (1999). Kandungan yodium pada beberapa bahan makanan di daerah pantai endemik dan non endemik. Buletin Penelitian Sistem Kesehatan, 3(1), 1-15. [In Bahasa Indonesia].

Herawati, E., Husna, S.A.N., Widiyani, T. and Budiharjo, A. (2021). Effect of red snapper fish intake on number of pyramidal cells in hypothyroidic rat brain model. IOP Conference Series: Materials Science and Engineering [Accepted].
Keller, H. E., Doenecke, D., Weidler, K. and Leppla, W. (1973). Kinetic studies on optimal conditions for the automated determination of low iodine concentrations by the Sandell-Kolthoff reactions. Annals of the New York Academy of Sciences, 220(1), 1-14. https://doi.org/10.1111/ j.1749-6632.1973.tb40246.x

Khan, Y.S. and Farhana, A. (2019) Histology, Thyroid Gland. Florida: StatPearls Publishing.

Lee, J., Yi, S., Kang, Y.A., Kim, H., Joung, K.H., Sul, H.J., Kim, K.S. and Shong, M. (2016). Morphological and Functional Changes in the Thyroid Follicles of the Aged Murine and Humans. Journal of Pathology and Translational Medicine, 50(6), 426-435. https://doi.org/10.4132/ jptm.2016.07.19

Mranani, F. (2014). Pedoman Skrining Hipotiroid Kongenital. Jakarta: Kementrian Kesehatan RI.

Mytilinaios, D., Nikolopoulou, E., Charchanti, A., Troupis, T., Kamilaris, T.C. and Johnson, E.O. (2017). The effect of short-term hypothyroidism on growth hormone secretory responses to growth hormone-releasing hormone (1-29) and insulininduced hypoglycemia. Acta Medica International, 4 (1), 81-87. https://doi.org/10.5530/ami.2017.4.15

Rajab, N.M.A., Ukropina, M. and Cakic-Milosevic, M. (2017) Histological and ultrastructural alterations of rat thyroid gland after short-term treatment with high doses of thyroid hormones. Saudi Journal of Biological Sciences, 24(6), 1117-1125. https:// doi.org/10.1016/j.sjbs.2015.05.006

Rastogi, M.V. and LaFranchi, S.H. (2010). Congenital hypothyroidism. Orphanet Journal of Rare Diseases, 5, 17. https://doi.org/10.1186/1750-1172-5-17

Soonawala, N.Z., Paul van Trotsenburg, A.S. and Verkerk, P.H. (2018). TSH and FT4 concentrations in congenital hypothyroidism and mild congenital thyroidal hypothyroidism. Journal of Clinical Endocrinology and Metabolism, 103(4), 1342-1348. https://doi.org/10.1210/jc.2017-01577

Skeaff, S.A. (2011). Iodine deficiency in pregnancy: the effect on neurodevelopment in the child. Nutrients, 3 (2), 265-273. https://doi.org/10.3390/nu3020265

Stelios, F., George, P. and Agathocles, T. (2007). The role of iodine in the evolution of thyroid disease in Greece: From endemic goiter to thyroid autoimmunity. Hormones, 6(1), 25-35.

Teixeira, P., Dos Santos, P.B. and Pazos-Moura, C. C. (2020). The role of thyroid hormone in metabolism and metabolic syndrome. Therapeutic Advances in Endocrinology and Metabolism, 11, 1-33. https:// doi.org/10.1177/2042018820917869 
Wassner, A.J. and Brown, R.S. (2015). Congenital hypothyroidism: recent advances. Current Opinion in Endocrinology, Diabetes and Obesity, 22(5), 407412. https://doi.org/10.1007/s40272-017-0238-0

Wassner, A.J. (2017). Pediatric Hypothyroidism: Diagnosis and Treatment. Pediatric Drugs, 19(4), 291-301. doi: 10.1007/s40272-017-0238-0. PMID: 28534114.

Whitbread, D. (2020) Top Foods Highest in Tyrosine. Retrieved on August 28, 2020 from myfooddata website: https://www.myfooddata.com/articles/hightyrosinefoods.php

Zamoner, A., Barreto, K.P., Filho, D.W., Sell, F., Woehl, V.M., Guma, F.C.R., Pessoa-Pureur, R. and Silva, F.R.M.B. (2008) Propylthiouracil-induced congenital hypothiroidism upregulates vimentin phosphorylation and depletes antioxidant defenses in immature rat testis. Journal of Molecular Endrocrinology, 40(3), 125-135. https:// doi.org/10.1677/JME-07-0089

Zbucki, R.L., Winnicka, M.M., Sawicki, B., Szynaka, B. andrzejewska, A. and Puchalski, Z. (2007.) Alteration of parafollicular (C) cells activity in the experimental model of hypothyroidism in rats. Folia Histochemica et Cytobiologica, 45(2), 115-21.

Zimmermann, M.B. and Boelaert, K. (2015) Iodine deficiency and thyroid disorders. Lancet Diabetes Endocrinolology, 3(4), 286-95. https:// doi.org/10.1016/S2213-8587(14)70225-6 